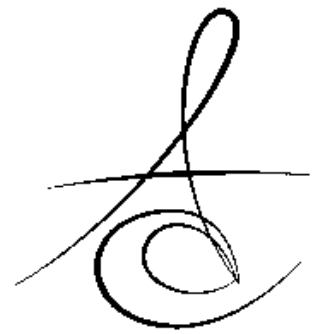

\title{
INVESTIGATION OF ENVIRONMENTAL LEAD CONTAMINATION CAUSED BY THERMO-ELECTRIC POWER PLANTS ${ }^{*}$
}

\section{TERMO ELEKTRİK SANTRAL KAYNAKLI ÇEVRESEL KURŞUN KONTAMİNASYONUNUN İNCELENMESİ ${ }^{*}$}

Yrd. Doç. Dr. Murat YEŞİL*

Prof. Dr. Zeynep YEŞİL DUYMUŞ ${ }^{* *}$

\author{
Prof. Dr. Nilgün SEVEN ${ }^{* * *}$
}

Makale Kodu/Article code: 2719

Makale Gönderilme tarihi; $\quad 26.03 .2016$

Kabul Tarihi: 20.06.2016

\section{ABSTRACT}

Chemical and radioactive gases are released to the environment from Turkey's largest thermal power plant located in Afsin-Elbistan region. Such gases remain suspended in the air, form a layer on the soil surface, seep into groundwater, may be carried to human body through foods and inhalation, and may accumulate in bones and teeth. In this study, accumulations of toxic elements emitted from the thermoelectric power plant in dental, soil, water and plant samples were analyzed. It was statistically determined that there was no significant difference ( $p>0.05$ ) between the values obtained in consequence of the variance analysis made with intent to evaluate the samples taken from the vicinity of the power plant examined within the scope of the research, and from the city of Yalova examined for control purposes.

Keywords: Thermal power plants, Tooth, Soil, Water, Plant

\section{öz}

Afşin-Elbistan bölgesinde bulunan Türkiye'nin en büyük termik santralinden kimyasal ve radyoaktif gazlar ortama salınmaktadır. Bu gazlar havada asılı kalır, toprak yüzeyinde bir tabaka oluşturur, yer altı sularına karışır, gıdalar ve solunum ile vücuda alınabilir, kemik ve dişlerde birikebilir. Bu çalışmada, termo elektrik santralden yayılan toksik elementlerin, diş, toprak, su ve bitki numunelerindeki birikimleri incelenmiştir.

Araştırma kapsamında incelenen termik santral çevresinden ve kontrol amacı ile incelenen Yalova ilinden alınan örneklerin değerlendirilmesi amacı ile yapılan varyans analizi sonucunda elde edilen değerler arasındaki farkın istatistiksel olarak anlamlı olmadığı ( $p>0.05$ ) görülmüştür.

Anahtar Kelimeler: Termik santral, Diş, Toprak, Su, Bitki

\section{INTRODUCTION}

In parallel with the increasing world population, need for energy use increased, as well. The requirements arising from the need for energy use leads humans to be in search of different energy sources but on the other hand, fossil-based energy production is still in the front rank. ${ }^{1}$ In Turkey, the 1970s were the years when the energy need was increasing rapidly, and the trend was toward thermal power plants because of the fact that they can be produced quickly, their cost of acquisition is low, and their external credit sources can easily be obtained. In those years, due to lack of adequate accumulation of knowledge in Turkey and the world about the potential environmental issues that might be caused by thermal power plants, and as a result, due to lack of public opinion in this regard, thermal power plants began to be built rapidly, without consideration of environmental issues. Although there are some other sources that can be used, such as fuel oil, coal is preferred for energy production in thermal power plants, because of its advantages such as that it can

*Department of Landscape, Faculty of Architechture, Ordu University, Ordu, Turkey

** Department of Prosthodontics, Faculty of Dentistry, Recep Tayyip Erdogan University, Rize,Turkey

*** Department of Restorative Dentistry, Faculty of Dentistry, Ataturk University, Erzurum, Turkey

₹5.Uluslararası Türk Prostodonti ve İmplantoloji Derneği Bilimsel Sempozyumunda poster

(Poster No: 201613) olarak sunulmustur.

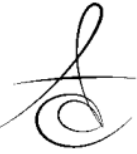


be quickly converted into energy, can be obtained inexpensively, and low-quality coals can be evaluated.

Several environmental problems not appeared in projects but experienced during the construction have been brought to agenda of Turkey with thermal power plants. Thermal power plants use significant amount of fossil fuels and create serious air pollution and have various negative impacts on ecological balance. Fly ash waste of coal-burning thermal power plants also creates serious problems. They are commonly stored over the land and hazardous components leached through the soil with precipitations and ultimately contaminate groundwaters. ${ }^{2}$ Millions of tons of fly ash are created by thermal plants through burning coal to produce electricity. Only $20 \%$ of such a huge source is reused and the rest is stored through retting or terrestrial fill. ${ }^{3}$

Heavy metals such as mercury, lead, cadmium, arsenic, nickel, copper and zinc emitted from the chimney of each thermal power plant cause permanent pollution in the air, water and soil, and are consequently taken to human body through respiration, food chain as well as the water used. ${ }^{4-7}$ In consequence of the scientific studies, negative effects of lead as a heavy metal on human health have been revealed, and the requirements for preventing its damages have been explained. ${ }^{8-10}$

The purpose of the study is to investigate the accumulation of lead in dental, soil, water and plant samples, which is one of the toxic elements that comes into existence as a result of combustion of the coal in thermoelectric power plants.

\section{MATERIAL AND METHODS}

Area of the power plant: Afsin- Elbistan thermal power plant located in $228.982 \mathrm{~m}^{2}$ area in AfsinElbistan plain situated $154 \mathrm{~km}$ north of the city of Kahramanmaras in the Eastern Anatolia region has continued its activities since 1984, with the capacity of $4 \times 344 \mathrm{MW} \cdot{ }^{11}$ In the power plant having a yearly production capacity of $8.100 .000 .000 \mathrm{kWh}$, lignite is used as the main fuel; and the daily main fuel requirement in full-load operation is 66.000 tons. $^{2}$

Providing dental samples: Birth places of patients, who visited the dentists serving in the vicinity of the power plant for tooth extraction, were asked, and the teeth of those who have not lived away from the region for a long time were accumulated, by recording the patient information (age, bad habits and gender). Each tooth was stored in a polyethylene tube in $-20{ }^{\circ} \mathrm{C}$. Teeth had no roots because of the physiological tooth restoration. Also, teeth with caries and fillings are discarded. A total of 30 teeth were collected. To remove residues of soft tissues prior to dissolution, the teeth were washed with $30 \% \mathrm{H}_{2} \mathrm{O}_{2}$. To check the possibility of lead losses during the washing procedure, six independent samples were leached with $2 \mathrm{ml}$ of $10 \% \mathrm{H}_{2} \mathrm{O}_{2}$, and the leachates were analysed after 1,5 and $24 \mathrm{~h}$. All absorbance values including the blank were within the interval 0.001-0.003 and without any significant trend with leaching time and within the noise level $(\leq 0.005 \mathrm{~A})$ of the instrument declared by the manufacturer. There fore, in further experiments the samples were leached in $\mathrm{H}_{2} \mathrm{O}_{2}$ overnight. After removing the soft tissue, whole teeth were washed by double deionized water, dried in a dry-box for $1 \mathrm{~h}$ at $80{ }^{\circ} \mathrm{C}$ and weighed into a glass vessel for dissolution. On average the weight of a human's whole tooth was $0.284 \mathrm{~g}$ (range 0.098-1.280 g). Samples were dissolved by rapid chemical reaction under control on a hot plate in $2 \mathrm{ml}$ of $65 \% \mathrm{HNO}_{3}$ and $0.4 \mathrm{ml}$ of $30 \% \mathrm{H}_{2} \mathrm{O}_{2}$ and after cooling diluted with double deionized water to the final volume of $10 \mathrm{ml}$. Dissolution was completed within 15 min.

Setting of measurement parameters instrument parameters were set as follows: Wavelength 283.3 $\mathrm{nm}$, slit width $0.7 \mathrm{~nm}$, slit height low, signal processing peak area, baseline offset correction $2 \mathrm{~s}$. Argon was used as purge gas delivered at a flow rate of $250 \mathrm{ml} / \mathrm{min}$. (stop-flow during atomization). Deuterium background correction was applied. The tubes were coated with pyrolytic graphite and equipped with an integrated L'vov platform. A matrix modifying procedure with $\mathrm{NH}_{4} \mathrm{H}_{2} \mathrm{PO}_{4}$ was applied to lead samples to control at the best matrix interferences, to circumvent the variability of sample drying procedure, and to minimize the unavoidable loss of Ptot during the charring/atomization step. Pyrolysis and atomization temperatures were investigated in the presence of $1 \% \mathrm{NH}_{4} \mathrm{H}_{2} \mathrm{PO}_{4}$ (50 $\mu \mathrm{g} /$ injection) as chemical modifier. Pyrolysis and atomization temperatures were selected at $850^{\circ} \mathrm{C}$ and $1300{ }^{\circ} \mathrm{C}$, respectively. Preparations of the standard and quality control $(\mathrm{QC})$ solutions $\mathrm{Pb}$ working solutions to $10,25,50,100,150,200,400,600,800,1000$

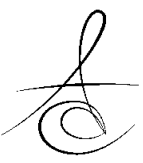


$\mathrm{ng} / \mathrm{ml}$ concentrations were prepared from the stock solutions $(100 \mu \mathrm{g} / \mathrm{ml})$ in deionized water. For the QC samples containing concentration $75,300,700 \mathrm{ng} / \mathrm{ml}$ of $\mathrm{Pb}$, the stock solution was diluted with deionized water.

Method validation: The peak areas were determined in six times. The calibration curves were obtained by a least-squares linear fitting of the peak area versus the amounts of lead. Intra- and inter-run precision were assessed from the results of QCs. The mean values and RSD for QCs at three concentration levels were calculated over six validation runs. These values were then used to calculate the intra- and inter-run precision (RSD) by a one-way analysis of variance. The accuracy of the method was tested using the Standard Reference Material NIST 1486 (bone meal) and expressed as the mean value. The precision and accuracy of each QC value should not exceed a deviation of $15 \%$, except for the QC samples for the limit of quantification (LOQ) where $20 \%$ was acceptable.

Providing the soil samples and preparing them for analysis: Soil samples were taken from the areas located $0.5,1,1.5,2,2.5,3,6,9,12,15$ and $30 \mathrm{~km}$ away from the power plant, towards the direction of the prevailing wind (from southwest to northeast), by checking the meteorological records. Sampling locations were made gradually less frequent, in parallel with the increase in the distance from the power plant. The soil samples taken with the method specified by Karaca et al. ${ }^{9}$ were dried in the shade, and then were screened through a $2 \mathrm{~mm}$ sieve. The soil analysis was made in Ataturk University Faculty of Agriculture, Department of Soil Science. Water sampling: Two-liter glass bottle and its cap (colorless, with a feature that would not affect the chemical structure of water) intended to be used for sampling was washed with hydrochloric acid solution $(\mathrm{HCl})$, rinsed thoroughly with pure water, and dried when kept upside down. The tap water connected to the water mains was run for two minutes, the glass water was rinsed with the sample water three times, and then the sample was taken and the cap was tightly closed by ensuring the airtightness. Water analyses were conducted by Erzurum Institute of Public Health.

Plant sampling: The plant samples taken from the vicinity of the thermal power plant were placed in paper bags, several holes were made in the bags for conservation of the samples, and then the samples were transported to Ataturk University Faculty of Agriculture, Department of Soil Science in a short time. During sampling, care was taken;

-To take leaf samples from the same types and varieties,

-Not to select diseased leaves showing too much nutritional deficiencies,

-To collect the leaves in the early morning hours of the day,

- To ensure the leaves to be dry.

As intended for control, teeth were collected and soil, water and plant samples were taken with the same methods from the city of Yalova considered to have low environmental pollution, and finally comparison was made.

Statistical Analysis: The obtained data were analyzed by analysis of variance and Student's t-test.

\section{RESULTS}

It has been shown that metals are incorporated into the dental tissues forming at the time of their exposure and the lead in teeth can be located in functionally and anatomically different parts of each tooth. Teeth are also good specimens because of being easily available materials. ${ }^{12}$ It was statistically determined that there was no significant difference ( $p>0.05)$ between the values identified in consequence of the variance analysis made with intent to evaluate the samples taken from the thermal power plant examined within the scope of control and research. In consequence of the analyses of the teeth, it was ascertained that although the lead amount $(15.33 \mu \mathrm{g} / \mathrm{g})$ in the teeth taken from the vicinity of the thermal power plant was greater than the lead amount $(11.51 \mu \mathrm{g} / \mathrm{g})$ in the city of Yalova examined for control purpose, the difference was not statistically significant $(p>0.05)$ (Table 1). Also, we could not observe a statistical significant correlation between man and women (Student's t-test, $P>0.05$ ). The average teeth lead level for man and women were found to be $12.12 \mu \mathrm{g} / \mathrm{g}$ (min-max, 4.13-26.83 $\mu \mathrm{g} / \mathrm{g}$ ) and $11.85 \mu \mathrm{g} / \mathrm{g}$ (min-max, 5.15-23.22 $\mu \mathrm{g} / \mathrm{g}$ ) (Table 2), respectively. 
Table 1. The mean and standard deviation results of the region.

\begin{tabular}{lcc}
\hline Region & Ortalama & Standart Sapma \\
\hline Afsin-Elbistan & $15.33 \mu \mathrm{g} / \mathrm{g}$ & 2.72 \\
Yalova & $11.51 \mu \mathrm{g} / \mathrm{g}$ & 1.61 \\
\hline
\end{tabular}

Table 2. The mean and standard deviation results of the sex.

\begin{tabular}{lcc}
\hline Sex & Ortalama & Standart Sapma \\
\hline Man & $12.12 \mu \mathrm{g} / \mathrm{g}$ & 4.31 \\
Women & $11.85 \mu \mathrm{g} / \mathrm{g}$ & 4.63 \\
\hline
\end{tabular}

\section{DISCUSSION}

Environmental contamination because of heavy metals is a matter of concern in many countries. ${ }^{12-14}$ Lead is one of the most important and widely distributed pollutants in the environment. ${ }^{15}$ Human activities and the extensive use of lead in industry have resulted in redistribution of lead in the environment and, hence, the contamination of air, water and food. As a consequence, the lead levels are significantly increased in the blood and body organs of human. ${ }^{16}$ It accumulates mainly in calcified tissues in the body, ${ }^{17}$ but the central nervous system is considered to be the critical organ of lead toxicity in children. ${ }^{18}$ From data published in the literature, lead is one of the elements accumulated mainly in calcified tissues, such as teeth and bones. ${ }^{19}$ Exposure to lead metal can be evaluated by measuring lead in blood, teeth, hair and bone, which are then used to estimate body lead burden. Lead accumulates in bones and teeth but the amount of lead released from teeth is negligible. Its annual aggregation in hard tissues can be considered to be directly related to blood lead levels. Thus, teeth are good indicators of environmental lead pollution and teeth have been extensively used as biological markers of exposure to environmental pollution. ${ }^{20-22}$ The teeth are a bioindicator of great interest because it contains information on exposure to elements that become deposited in the tooth material. The mineral tissue of the tooth consists of hydroxyapatite crystals with incorporated trace elements which can provide information, concerning environmental influence and dietary habits. ${ }^{12}$ Lead is not used in dental restorative materials, but traces of lead have been found as contaminations in filler particles of glassionomer and composite fillings in insignificant concentrations habits. $^{23}$

In this study, findings similar to that of Lappalainen and Knuuttila ${ }^{21}$ were obtained. Gomes et al. ${ }^{24}$ determined the amount of lead in the superficial enamel of deciduous teeth from 4- and 5-year-old children both in industrialized and non-industrialized areas in Piracicaba, Brasilia. The levels of lead were 220 and $140 \mu \mathrm{g} / \mathrm{g}$ in industrialized and nonindustrialized areas, respectively. Piracicaba has an industrial area in which a battery factory operates. They reported that no significant difference between industrialized and nonindustrialized regions in terms of lead concentrations was observed. They used the surface enamel part of tooth which has much more lead than the inner enamel or whole (dissolved) teeth. Omar et al., ${ }^{25}$ found a significant difference and attributed this to the greater industrialization of many parts in Egypt; more exhaust fumes from cars, industrial emissions and use of canned food and possible water contamination. Karakaya et al., ${ }^{26}$ examined the content of lead of 7-12 age children deciduous teeth collected in suburban and urban areas of Ankara to be the capital of Turkey. Karahalil et al., ${ }^{27}$ examined the content of lead of deciduous teeth collected from 4-15 age children who have been living in areas of Ankara and Balıkesir.

Epidemiological studies have shown that the skeleton contains most of the lead body burden in humans (about $90 \%$ in adults and $70 \%$ in children). ${ }^{17}$ The more polluted the environment, the higher the lead level in teeth. Thus, differences in the lead level were found between urban or industrial areas and rural zones or between different areas of the same city. ${ }^{26-28}$ Experimental evidence shows a doseresponse relationship between blood lead and dentin lead. Also, increasing lead levels have been documented in permanent teeth with increasing age. ${ }^{29}$ The results obtained in this study were obtained in a way specified in the literature, and the values were found to be higher than the values obtained by Aladag et al. ${ }^{30}$ who have investigated the lead amount in deciduous teeth. In their study carried out in Leinigerwerk Thermal Power Plant, Bunzl et al. ${ }^{8}$ took soil samples from 0.4, 0.8, 1.4, 2.7 and $5.2 \mathrm{~km}$ away from the power plant; collected fly ash samples from 
electrostatic collectors at 4 different time for 2 years; and analyzed them. According to the analysis results, $\mathrm{Pb}$ content, $\mathrm{Co}$ content, and $\mathrm{Ni}$ content of the ash samples were defined to be $3680 \mathrm{mgkg}-1,122 \mathrm{mgkg}$ 1 , and $325 \mathrm{mgkg}-1$, respectively.

Also in this study, the amount of lead in the soil samples taken from the vicinity of the thermal power plant was decreased in parallel with the increase in the distance from the power plant. The amount of lead in the location at the closest distance from the power plant was $13.96 \mathrm{mg} / \mathrm{kg}$, and it decreases as inversely proportional to the distance $(4.65 \mathrm{mg} / \mathrm{kg})$. The amount of lead in Yalova city center is $7.20 \mathrm{mg} / \mathrm{kg}$, while it reduces to $2.52 \mathrm{mg} / \mathrm{kg}$ in the sampling area. It was ascertained that although the difference between the values obtained at the centers and vicinities of the both research areas was significant, the difference between the two areas was not statistically significant. This situation can be attributed to factors such as exhaust fumes that lead to environmental pollution in the center of Yalova. As a result of the evaluation of the water samples taken from the thermal power plant and the city of Yalova, it was ascertained that the results obtained from the both places showed compliance with the standard values. In the analysis of the plant samples, although trace amount of heavy metals such as lead $(0.053$ $\mathrm{mg} / \mathrm{kg}$ ) were found in the plants taken from the vicinity of the power plant, metal was not found in the plants taken from the city of Yalova.

\section{REFERENCES}

1. Tuna AL, Girgin AR. Mısırda (Zea mays L.) Gelişme, mineral beslenme ve ağır metal içeriği üzerine Yatagan termik santral uçucu küllerinin etkisi. Ekoloji 2005;14:7-15.

2. Karaca A. Afsin-Elbistan termik santralı emisyonlarının çevre topraklarının fiziksel, kimyasal ve biyolojik özellikleri üzerine etkileri. Pamukkale Üniversitesi Mühendislik Fakültesi Mühendislik Bilimleri Dergisi 2001;7:95-102.

3. Sengul U. Kangal termik santrali'nde uçucu kül atımının çevresel etkileri. Ekoloji ve Çevre Dergisi 2002;11:21-4.

4. Baba A. Yatağan (Mugla) termik santralı atık depolama sahasının yer altı sularına etkisi. Jeoloji Mühendisliği 2001;25:1-19.
5. Egemen E, Yurteri C. Regulatory leaching tests for fly ash: a case study. Waste Management and Resource 1996;14:43-50.

6. Bakar C, Baba A. Metaller ve Insan Sağlığı: Yirminci Yüzyıldan Bugüne ve Geleceğe Miras Kalan Çevre Sağııı Sorunu. 1.Tıbbi Jeoloji Çalıştayı, 30 Ekim-1 Kasım 2009, Ürgup Bld., Kultur Merkezi, Urgup/ Nevsehir, 2009.

7. Bertine KK, Goldberg ED. Fossil fuel combustion and the major sedimentary cycle. Science 1971; 173:233-5.

8. Bunzl $K$, Rosner G, Schmindt W. Distribution of lead, cobalt and nickel in the soil around a coal fired power plant. Z Pflanzenernaehr Bodenk 1983;146:705-13.

9. Karaca A, Turkmen C, Arcak S, Haktanir K, Topçuoglu B, Yildiz H. Çayırhan termik santralı emisyonlarının yöre topraklarının bazı ağır metal ve kükürt kapsamlarına etkilerinin belirlenmesi. AÜ Çevre Bilimleri Dergisi 2009;1:25-41.

10. Selinus O, Alloway B, Smedley PL, Centeno JA, Finkelman $R B$, Fuge $R$, Lindh $U$. Essentials of medical geology: impacts of the natural environment on public health. Amsterdam; London, UK, Elsevier 2005:812.

11. Ural S, Dag A, Gunes M. Afsin-Elbistan A (Kıslakoy) Acık Isletmesinde Optimum Ocak Sınırlarının Belirlenmesi, Yayla - Madencilik Kongresi, Izmir, 912 Haziran 2005.

12. Frank RM, Sargentini-Maier ML, Turlot JC, Leroy MJF. Comparison of lead levels in human permanent teeth from Strasbourg, Mexico City, and ruralzones of Alsace. J Dent Res 1989;69:903.

13. Bu-Olayan AH, Thomas BV. Dental lead levels in residents from industrial and suburban areas of Kuwait. Sci Total Environ 1999;226:133-7.

14. Blaha K, Bencko V, Cikrt M. Exposure to lead and human health in the Czech Republic. Centr Eur J Publ Health 1996;4:233-41.

15. Alomary A, Al-momani I F, Obeidat SM, Massadeh AM. Levels of lead, cadmium, copper, iron, and zinc in deciduous teeth of children living in Irbid, Jordan by ICP-OES: some factors affecting their concentrations. Environ Monit Assess 2013;185:3283-95. 
16. Al-Mahroos F, Al-Saleh FS. Lead levels in deciduous teeth of children in Bahrain. Ann Trop Pediatr 1997;17:147-54.

17. Steenhout A. Kinetics of lead storage in teeth and bones: an epidemiological approach. Arch Environ Health 1982;37:224-31.

18. WHO (World Health Organization). Lead. In: Air Quality Guidelines for Europe. World Health Organization, Copenhagen, 2005:1-13.

19. Zhang ZW, Moon CS, Watanabe T, Shimbo S, He FS, Wu YQ, Zhou SF, Su DM, Qu JB, Ikeda M. Background exposure of urban populations to lead and cadmium: Comparison between China and Japan. Int Arch Occup Environ Health 1997;69:273-81.

20. Hernández-Guerrero JC, Jiménez-Farfán $M D$, Belmont R, Ledesma-Montes C, Baez A. Lead levels in primary teeth of children living in Mexico City. Int J Pediatr Dent 2004;14:175-81.

21. Lappalainen $R$, Knuuttila $M$. The concentration of $\mathrm{Pb}, \mathrm{Cu}, \mathrm{Co}$ and $\mathrm{Ni}$ in extracted permanent teeth related to donor's age and elements in the soil. Acta Odontol Scand 1981;39:163-7.

22. Bercovitz K, Laufer D. Age and gender influence on lead accumulation in root dentine of human permanent teeth. Archives Oral Biology 1991;36:671-3.

23. Oilo G. Biodegradation of dental composites/glassionomer cements. Adv Dent Res 1992;6:50-4.

24. Gomes E, Sousa MLR, Barbosa F, Krug FJ, Saraiva MCP, Cury JA, Gerlach RF (2004). In vivo studies on lead content of decidious teth superficial enamel of preschool children. Sci Total Environ 2004;320:25-35.

25. Omar S, Rayes A, Eqaab A, Voß I, Steinbuchel A. Optimisation of cell growth and poly (3hydroxybutyrate) accumulation on date syrup by a Bacillus megaterium strain. Biotechnol Lett 2001;23:1119-23.

26. Karakaya A, Ilko M, Ulusu T, Akal N, Isimer A, Karakaya $\mathrm{AE}$. Lead levels in deciduous teeth of children from urban and suburban regions in Ankara (Turkey). Bull Environ Contam Toxicol 1996;56:16-20.

27. Karahalil B, Aykanat B, Ertaş N. Dental lead levels in children from two different suburban areas of Turkey. Int J Hyg Environ Health 2006;210:10712.
28. Nowak B, Kozłowski H. Heavy metals in human hair and teeth. Biological Trace Element Research 1998;62:213-28.

29. Lyngbye T, Hansen ON, Trillingsgaard A, Beese I, Grandjean P. Learning disabilities in children: significance of low-level leal exposure and confounding effects. Acta Pediatr Scand 1990;79:352-60.

30. Aladag H, Yılmaz B, Hacer T, Kadıoglu Y, Seven N. Lead levels in saliva and blood of adults living in three different areas of Turkey. International Journal of Pure and Applied Chemistry 2010;5:1517.

\section{Yazışma Adresi:}

Prof. Dr. Zeynep YEŞİL DUYMUŞ

Recep Tayyip Erdoğan Üniversitesi

Diş Hekimliği Fakültesi Protetik Diş Tedavisi

Anabilim Dalı, Rize

E Mail: zyesilz@hotmail.com 